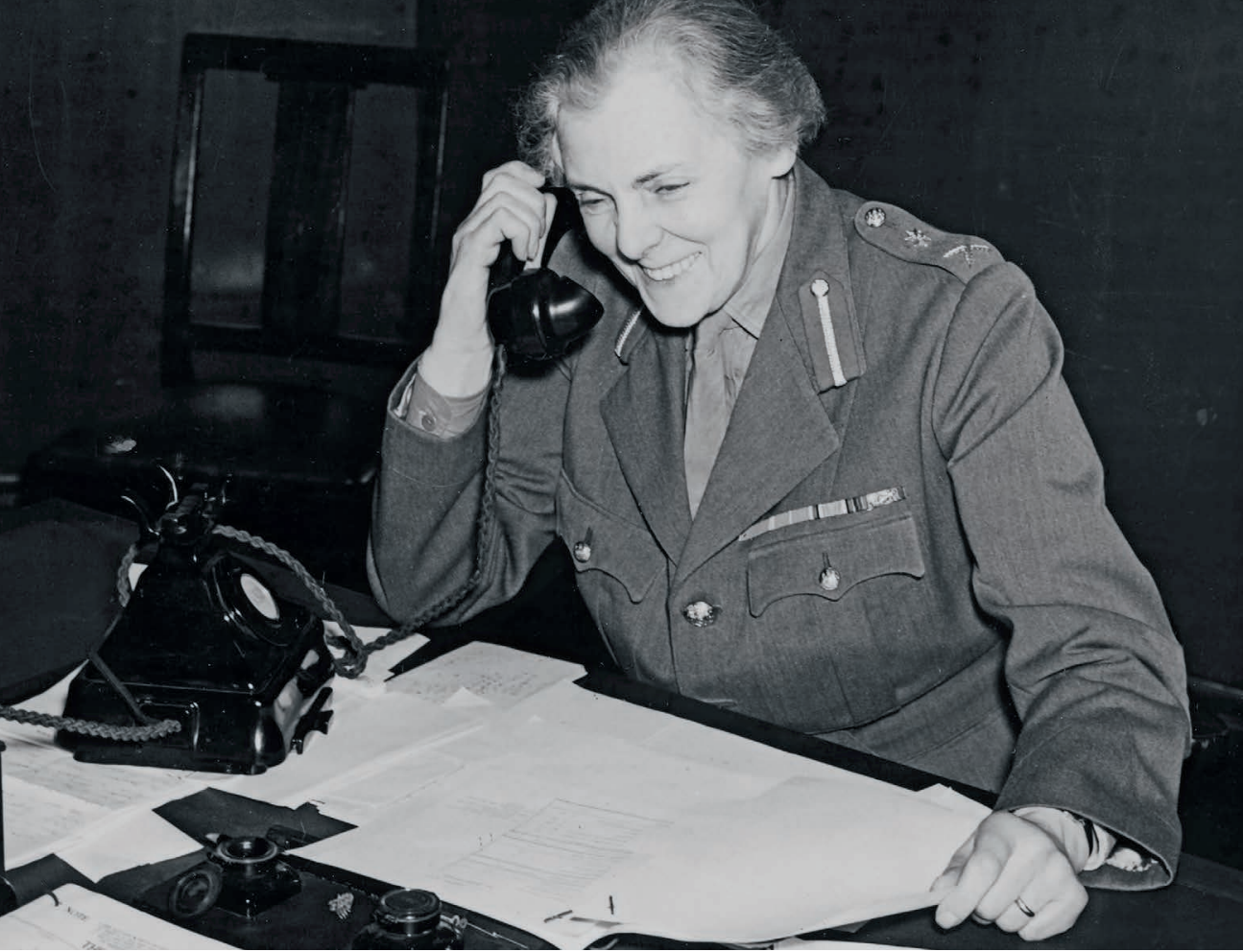

Botanist Helen Gwynne-Vaughan was controller of the British Women's Army Auxiliary Corps.

\title{
HISTORY
}

\section{Science and suffrage}

\section{Elizabeth Bruton lauds a book tracing how women in wartime research blazed a path to the vote and beyond.}

A century ago, women over 30 were granted the vote in Britain. (US women gained the vote two years later, although African Americans and Native Americans were still effectively disenfranchised for some years.) The UK watershed coincided with the end of the First World War. Historian of science Patricia Fara commemorates the moment with A Lab of One's Own, using archival research to draw together narratives of science, war and suffrage (as she trailed in an essay: Nature 511, 25-27; 2014).

The standard take on this period is that British women gained opportunities through labour shortages, the result of 6 million men going to war. Thus, women were able to enter fields such as science, technology, engineering, mathematics and medicine (STEMM).

Fara's story differs. She shows how women's entry into these areas was shaped by the prewar efforts and example of exceptional women including archaeologist Agnes Conway; biochemist Ida Smedley; and political campaigner Ray Strachey, related to Virginia Woolf. (The title of Fara's book, suggested by historian Marsha Richmond, was inspired by Woolf's classic 1929 'A Room of One's Own')

Along with agitating for the vote, these women called for more than the traditional roles of domesticity, clerical work, nursing and teaching. They lobbied for professional opportunities, financial independence and

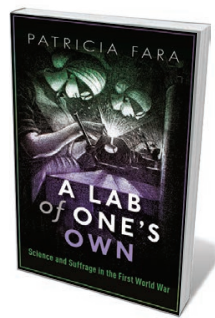

higher degrees. Fara shows how they created opportunities in research, medicine, intelligence and codebreaking. They opened doors in factories, academia, hospitals and the battlefield.

They also fought the

A Lab of One"s Own: Science and Suffrage in the First World War PATRICIA FARA Oxford University Press: 2018. \section{belief that women were} inherently lesser than men, shaped by biological justifications, including eugenics. Charles Darwin and founder of taxonomy Carl Linnaeus, Fara claims, used their theories to argue for the impossibility of sexual equality. In 1904, chemist Henry Armstrong argued that, because women were thought to be lower down the evolutionary scale, "education can do little" to modify their nature.

Fara's nuanced narrative centres on a group of scientific and medical women, many of them graduates of Newnham College, Cambridge. Strachey studied mathematics before turning to politics, fighting for women's economic, professional and political power before, during and after the war. Conway studied history and chronicled women's work. Smedley was the first woman admitted to the London Chemical Society.

Among the non-Newnhamites, Caroline Haslett rose from the post of clerk at the Cochran Boiler Company (which made parts for ships) to train as an engineer during the war. Later, she became the first female member of the British Electricity Authority. Formidable Scottish geologist Maria Gordon was the first woman to be awarded a doctor of science from the University of London, in 1893. This group is completed by the "scientists in khaki" and leaders of the Women's Army Auxiliary Corps, physician Mona Geddes and botanist Helen Gwynne-Vaughan.

Fara also highlights achievements of lesser-known women. We meet aeronautical researcher Beatrice Mabel Cave-BrowneCave; spycatcher Mabel Elliott; and the diplomatic-mail readers of the Admiralty's Room 40 who, with their codebreaking counterparts, saw their covert wartime work persist into peacetime. Fara discusses, too, medical luminaries such as Helena Gleichen and Nina Hollings, who worked in new fields including radiography and physiotherapy. Interwoven are fascinating glimpses of women about whom "only snippets of information" survive. Fara's retrieval of them makes this narrative more than the sum of its parts.

But winning the war, and the vote, did not result in equality: it would be another decade before the Equal Franchise Act of 1928 granted voting parity. And the interwar years saw a return to prewar mores. Male veterans reclaimed jobs, and women's opportunities dried up, among expectations that they would return to the kitchen.

If there is a weakness in Fara's approach, it is that the focus on Cambridge graduates veers close to a 'Great Women' echo of the 'Great Men' history that Fara criticizes. She does acknowledge, if sparsely, difficulties experienced by working-class women, for example in gas production and munitions. Nevertheless, she shows how women and their wartime work changed perceptions of female roles and competency, and influenced professional and educated women earning their own living. In 1919, the Women's Engineering Society was founded. A year later, the University of Oxford granted women the right to graduate.

The wartime changes were neither longstanding nor wide-ranging. But they were - Fara argues - catalysts for many positive shifts in the workplace. The discrimination experienced by many of the women in A Lab of One's Own is now illegal. Fara concludes with an open-ended question: how can what we learn from this history challenge other historical interpretations, and so inform the future narratives of women in STEMM? -

Elizabeth Bruton is curator of technology and engineering at London's Science Museum. e-mail:elizabeth.bruton@sciencemuseum. ac.uk 